\title{
Style and Skill: Critic's Artistic Ability
}

\author{
Kadirova Nasima Saidburhonovna, Akhmedova Shoira Ne'matovna
}

\begin{abstract}
The problem of the style of literary scholars or critics is one of the few studies in literature. The method of literary criticism is the individuality, originality in understanding, researching and analyzing fiction. The style is formed, first of all, by the nature of the scholar's understanding and perception of the work of art. A critical or literary scholar's method is to determine the language, genre, composition, realities and secrets of his article or research, use analysis techniques, pathos, links to life, artistic tastes, and independent observations about life and reality, human and future. It stems from the specificity of the description.

The literary critic Ibrohim Haqqulov has his own style, and the article analyzes his work in various ways, including the understanding of the text, the specificity of the methods, the genre's diversity and the role of literary criticism.
\end{abstract}

Keywords : literary critic, critic, classical literature, skill, style, scientist's remarks, critic, method, cultural method, historical-cultural method, genre, article,essay.

\section{INTRODUCTION}

It is important to note that Ibrahim Haqqul, a well-educated and well-respected literary writer, was born in the Uzbek literary atmosphere between the two centuries, i.e. during the era of national revival and independence. In the time of our national culture revival, we have to admit that the emergence of self-sacrificing scholars was a great necessity."You are known as our mature, competent researcher and propagandist of classical literature among our people" [1.234]. This is the confession of the Hero of Uzbekistan Ozod Sharafiddinov to Ibrahim Haqqul which was told ten years ago and became the conscience of our literature.

Indeed, Ibrahim Khakkul, who was a student of the Bukhara State Pedagogical Institute at the end of the 1960s, dreamed of similarity to her dearly loved writers Oybek, Khahhor who have worked hard at the communist system, studied the life and creativity of the secrets, along with his scientific work, had his own independent, honest view of the world and literature, and he maintained his identity of human personality, humanity, and patriotism which are considered to be the main purpose of literature.

Literary critic worked in different spheres, in a multitude way. For example, the first is classic literature, and particularly, in navigational studies. Secondly is Sufism.

Revised Manuscript Received on July 22, 2019.

KADIROVA NASIMA SAIDBURHONOVNA,

A Researcher of Bukhara State University, Uzbekistan. Email: nasimasaidzoda@mail.ru

AKHMEDOVA SHOIRA NE'MATOVNA.

A Doctor of philological science, Bukhara State University, Uzbekistan
Third is a comparative literature (in a sharp western emblem). Fourth is the objective history of literature. Fifth is a purely literary criticism. Sixth, the attitude to the period and the social environment ... It is possible to continue this count, unfortunately, we have not yet been able to fully study the creativity of the scientist. Most important, Ibrahim Khakkul has topic of challenges and problems of nation in all his articles, brochures or interviews, whether it belongs to our past or our present-day literature. It defines the high status of literature.

\section{MATERIALS AND METHODS}

The scientist's book, Irfon and Cognition (1998), is devoted to the study of the less-studied ideological and artistic directions of our classical literature, which has a rich history. It explains and analyzes the secrets of creative achievements of great Oriental poets like Ahmad Yassavi, Suleiman Bogirghoni, Jaloliddin Rumi, Alisher Navoi, and many scholars of Oriental mysticism and eloquent poetry in the East. His works have been studied. In the book "Return to Navigation" (1989), "Return to Navoi" (2011), the works of Alisher Navoi are analyzed in new ways and his works are brought to the public. The book "Life, Literature and Eternity" (2019) is devoted to the actual topics of classical and modern poetry and contains articles by I. Hakkulov in various genres. Few scholars whose literary methodology has been tested in literary criticism, including I. Hakkulov's work, have been poorly studied, and some articles on scholarly activity have been written. For example, in the article "The Symbol of Honesty and Cleanness in Criticism" in M. Kushzhanov's book "Heart and Appearance", critics U.Normatov, I.Gafurov, E.Karimov, N.Hudoyberganov, M.Nurmuhammedov commented on the reviews of the work of Uzbek critics. receive. His articles, published in the central editions, correctly acknowledge that the issues of Uzbek literature are being evaluated at the all-Union level.Literary scholar L. The last section of Kayumov's book "Asr and Prose" is called "Literary Criticism and Creative Process", which analyzes the activities of Uzbek critics and also expresses his opinion on I.Hakkulov.

The same can be said about the articles of literary critic S.Mamajonov, B.Nazarov, O.Togaev. Because in their review articles, some other critics have commented on the work of I. Hakkulov. For example, S.Mamajonov in his article "Deepness in science" noted that I. Hakkulov's book "Rubai in Uzbek Literature", "The Poetry of Uvaysiy" and articles published in the periodical press give him a sense of hope for the future. The article used mainly the methods of analysis and comparative analysis in the analysis and study of critical works. Also, using biogeographical method, general conclusions 
about the personality and creativity of the critic based on the investigated works were given.

\section{DISCUSSION}

The first thing that is most evident in the articles and interviews of Ibrahim Haqqul is his thoughts on society and people rather than his scientific analysis. In this sense, he is not only a literary critic, but also a philosopher. For example, the scientist's article about Mansur Khalloj begins: "It is possible to speak openly in this universe only with the intelligent, spiritually strong, free person - the brave Person. Anyone who has no independent vision and who is deprived of his ability to think independently can never be his 'own'. He knows everything that he knows, and everyone is embraced by the soul and mood that he is accustomed to, and that stagnation and ignorance never touch him. In ancient times, the word "animal" was used to describe such people. When the search for truth begins, a new life will be there. Sufism is thus a doctrine that reveals the purpose of changing people's minds and bringing new things to life. Sufism emphasizes the human's obedience to Allah and promotes a radical improvement in the concept of man's dependence on human beings. It was also about beliefs such as freedom and equality "[3,336]. The introduction of the article "The Spirit of Honor, the Honorable Poet" by Jaloliddin Rumi is as follows: "Thousands of years ago, there was a fox in the ancient Chinese village. The villagers said, "What do you carry with you? "He replied," The whole world. " The world", which was referred to by this wise man, was truth, and he has been busy with promoting and propagating the truth to the people who were seeking truth. Many of the great poets and writers born in the East resemble to this wise man. They are also talented, who have seen the world in the Truth, born to Truth, dedicated their lives and activities to the prospect of Truth. Truth does not consist of unity of fixed ideas and concepts. The renewal of the truth is powerful and hopeful, with its ever-increasing progress. That is why when the truth rises to elevate positions every time, there are positive changes in the universe and Adam's destiny. Social, political and economic injustices are partially eliminated. And it spontaneously enhances people's confidence in the truth. Thus, the highest ethical feelings are awakened. "[3.338]

In both of these articles, the author has written his thoughts on the individual, society and truthtriangle before the subject is examined. The author finds that the reader should be interested in the essence of the conversation first, in order to "talk" on a difficult topic such as Khalaj or Rumi. This means that, besides being a well-educated writer, it is necessary to have a little vocabulary, a little philosophic ability. Here is the result of skill, simplicity, and depth of mind in the way of thinking and writing!

Ibrahim Khakkul has published more than 30 books as an author during his creative career. We also know that there are dozens of literary-educational talks, other articles and speeches that have not yet been published. As we mentioned earlier, he is a great scholar. However, the main scientific direction is Oriental classic literature. Throughout his forty years of his first scientific work, Rubait in Uzbek Literature, he has been the subject of classical literature - the idea ofa prospectiveperson and all the common human views united around this idea, analyzes. At the same time, in the literary criticism, the novel approach to the creation of Navoi and the literature of Sufism among the literary community. Hayitmetov, N. As well as the famous scientist Kamilov I. It is worthwhile to say that he has a great deal of service.

The book "Spirituality and perception" by the literary scholar is dedicated to the study of the ideological and artistic directions of our classic literature, which has a rich history of many centuries. The masterpieces of creative achievements of the great poets of the East, such as Ahmad Yassavi, Sulayman Bakirghoni, Jaloliddin Rumi, AlisherNavoi are being interpreted and analyzed.

It is noteworthy that the scientist's views about Sufism and Literature, the main features and qualities of the Uzbek Sufism literature, were rarely studied in science because of the role of tasawwuf in the thinking of the Orient Peoples. I. Hakkulov first studied the level of manifestation of Sufism and poetry in Uzbek literature. "The poem of Sufism comes to the conclusion that the poetry, which has deeply studied the spiritual life of a man, has a profound and complex psychic state."When you read analyzes and interpretations of the poem of Ahmad Yassaviy, Alisher Navoi, and Bobur's poems, you will feel the love of the literature and the love to the word.

I.Hakkulov monitors and responds to every new book or article about Sufism and great Sufi life. Sometimes, some of the erroneous views are denied by grounded evidence.. One of the proofs of the Sultan's "Bahouddin Naqshband Eternal Era" is not satisfactory. First of all, the essence of this brochure is sincere about the courage and experience of the aged, selfless scientist. It is also difficult to believe that the scientist Sultan Muhammad ibn Jalal al-Din, or Naqshband, was a concubine of Sultan Khalil for some time, and that it was difficult to accept and accept the views that Bahauddin was from our grandfather's grandmother. Correctly recognizes. He himself explains that this is not true, based on various historical sources and essentially the essence of tasawwuf. For this, he expresses the view that the Turkish scientist Prof. AsadJoshan has different views on not understanding the essence of sufism.

The scientist pointed out an article by Ahmad Zakidi Walidi Tugan, "Gozan Khalil and Bahouddin Nakshband", a legend of Amir Kulol, an essay of one of the Indian scholars on the Buddha, and based on the opinions of Imam Rabbani and Bertels, and suggests that he did not. The Indian theologian's thoughts are close to psychological death: "The essence of Sufism is also closely related. And murshid or murids, who did not dare to harm the flies in real life, were busy with "jail" without hesitation. ..." [4.82]. It seems that the scientist attempts to base his views on historical sources.

If we pay attention, the efforts to bring AlisherNavoi's works to the vast majority of people in literature in the period of independence were limited to the interpretation of rubaits and gazelles, the prose of poems and explanation of their essays. (With the exception of academical research, such as SadriddinAini, Abdurauf Fitrat, Olim Sharafiddinov, Oybek, Aziz Kayumov).

Ibrahim Khakkul's collections of "Zanjirband sher qoshida" and "Kamol et kasbkim ..." published in the late 80s of the last century, contained comments on Navoi's works. However, any reader immediately knows that these 
comments are rich in ideas and thoughts, which, in contrast to what was said during the periods of desperate state and in the textbooks of the school and higher educational institutions.

It is noteworthy that I. Hakkulov wrote almost all the articles in the book "Under the Lieutenant Colonel", covering a wide circle of readers, avoiding academic linguistic templates and annoying phrases, and in the first line of the story, most articles begin with an interesting narrative or idea. Looking back at the articles of the book "Back to Navoi" and "Fate and perspective", which were published in the post-independence period twenty years after the scientist, we find a completely different view of the original books. Of course, this is a creative upsurge.

The book "Back to Navoi-2" is divided into three parts by the author.

1. Wisdom of love and understanding. This section includes the article about Ibrahim Khakkul's research on navigational issues in Uzbek literature, articles about new interpretations, as well as the inscription on the birthday of a great thinker and writer in connection with the publication of many works by Navoi.

2. Comments and interpretations. This section contains commentaries written in original interpretations of Navoi's several bytes, gazelles and other small works.

3. Literary conversations. In this section, Ibrahim Haqqul has been interviewed by journalist, writer, or literary critic on various subjects and on various topics related to Navoi's creativity.

Analyzing the novel of Navoi, which begins with the famous "Yordin ayru ko`ngul ..." the critic will focus not only on romantic ghosts but also on its socio-political relevance. The critic, first of all, looks at the way of Navoi. In 1447, Shohruh Mirza's death, ruler of the reign, the Navoi's father and his family moved to Iraq, reminding the reader of the tragic state of the abandoned country in the memory of the young poet in 1447. And in the light of this, it has been proven by a consistent logic that is critically critical, that the discovery of the essence of the super-ego property-the impossibility of the inanimate entity.

The fate of the state without the sultans is broader and deeper than the darkness of the lifeless body in the next byte, compared to the dark earth, the unseen night, the moonless night, and the darkness of life without water, he says. Indeed, through its in-depth analysis, the widespread and up-to-date aspects of this lyric are revealed. This gazelle, which was considered by many readers as one of the best examples of romantic gazels, was read and studied by many readers, I. Khakkulov once again presented his reader with a new look. It was evident that Navoi did not just describe the state of the lover in this gazelle, and he was able to exaggerate the sad state of the whole country in such a beautiful romantic situation.

The deeper, the more mature, the more mature the analysis, the stronger the conviction. I.Khakkulov interprets and interprets each and every byte of such a deep and consistent way that one can not be surprised at the ability of the genius artist to use words and images as Navoi.

Literary critic Ibrohim Haqqulov states that "Having own style is having an own personality". While we learn Ibrohim Haqqul's literary activity, we can notice his personal style that does not similar with other literary critics. Whenever he analyzes Navoi's gazelles, he always relies on analyzing the author's personality, mood, and spiritual sensations. He uses a lot of analyzing methods. In the article titled "Poetic text and image expressiveness" of his authorial book "Back to Navoi 2," describes the text analysis principles. Particularly, the most important point of his analysis is to understand the meaning of the word and not to miss its associated meanings in an associative case. In the article scientist analyzes in comparative method Navoi's rubai, which begins with "In estrange destitute never be gaiety..."

In the beginning of the article, I. Hakkul made an attention the essence of the word "g urbat" (estrange), its broad and cramped meanings, and in what meaning it is used in tasavvuf. The scientist uses the semiotic and linguistic methods of analysis for revealing the real meaning of the word. In order to know for surely what meaning used Navaiy, by using of the word " $\mathrm{g}$ 'urbat" in this rubai, critic tried to compare this word with another genre works of the great poet.

However, the phrase "all praise is forbidden" which was used in the Navoi slogan, means that the other world, the hereafter, on the other side, the couplet "one wants rendezvous, seeks for estrange" shows another meaning of the word "g urbat" (estrange). Moreover, the scientist paid his attention to, what Navai meant by saying the couplet "Navai, rejoice in all way, out of estrange". The scientist stated that the words "estrange" and "stranger" which were used in various meanings, are the key words in the Navai's rubai and furthermore, it is necessary to pay attention not to linguistic, but the other meanings of the words. And, he paid his attention A.Hayitmetov and Yo. Isakov's analysis and styles.

These scientists have studied this text based on historical-comparative and creative-genetic analysis, and made a notice on the linguistic meaning of the word "estrange", which has the meaning separation from the homeland.

Ibrahim Haqqulov intends to study this rubai in his own individual style, and guides the method of historical-cultural analysis. The scientist himself thought a question that if Navai, who was the inspiration of many creators, had an influence for writing this rubai. Continuing his research, the scientist cites the couplets of Persian poets such as Hafez Sherozi and Sano, and explains the literary background of the word "estrange" by the examples Plato, the Monotheism, the Islamic Sufi and the Mutasavvism teachings. The meaning of the words "estrange" and "stranger", in the Islamic world is explained by the teachings of the hadis, tasavvuf scholars such as Abdurazzaq Koshani, Ibn Arabi, Abdukarim Jiliy and Abdullah Ansari.

According to the scientist, Navai referred to the fact that the essential meaning of the "estrange" is not only separation from the homeland, but also the phenomenon that changes sublime, divine will and a unique attribute. Thus, scientist who is well-aware of tasavvuf teachings and who was the criterion of this teaching, analyzed Alisher Navai's above-mentioned rubai of the through the historic-cultural methods of studying, could caught new perspectives of the points, gave these ideas to other learners. 
Ibrahim Haqqul's article about "The changing the word into image in Navai's poetry", the author drew the point on which one should pay attention while analyzing of Navai's creativity and noticed to shortcomings made by some researchers. However, the scientist infers that in many analyzes, insincerity and misinterpretation are mostly an analysis of a creator's particular byte, since a single word or phrase simply does not refer to a creator. Accordingly, the learning through historical and cultural analysis prevents the researcher from misinterpretation of the content.

In this article, the scientist interprets Navai's most commonly used "ayoq" (dish), "turki yagma" in the same analysis method. At first glance, "turki yagma" is a ghostly bloodthirsty manifestation, but in Navoi's poetry it is evidenced by the evolution of the image as a positive phenomenon. The scientist emphasized that these phrases were used also in Lutfiy, Sadiy, Rumiy, Khujandiy and Jomiy's poetry, and all of these literary had not have the meaning bloodthirsty manifestation. In ancient times, there was "xoni yagmo" event, which was portrayed in "Kitobi Dada kurkut", moreover, the "Devoni lugoti Turk" also had such kind of information. The scientist used this information in order to explain deeply the words "yagmoi turk" and "xoni yagmo" and other meanings in East poetry, stating that Navai's poetry should be analyzed based on these facts. The article includes the phrases "qora rang" (black color) and "toji torak"(black crown) which are shown in the same method of analyzing, furthermore, scientist based on formation which is very clear to other learners.

The clever critic of Navoi's poetry goes to the analysis of the notion that it is connected with life, the era, the future of the country, and its connection with religion and philosophy.

Summarizing these analyses, the scientist has created a new and valid analysis through the historical and cultural methodology. We can easily see the scientist's intention and his point of view while writing his any creation. Especially, using of this method in the analysis of Navai's poetry, paying the attention to the teaching of tasavvuf, took him closer to the spirit and view of the great poet. I. Hakkul's analysis proved that Navai's poetry has various views and each view relies on great knowledge and comparison of every detail. And this of course, factors determining the method of the scientist and shows that he is unique in the use of various methods.

I.Khakulov's works are distinguished not only by the range of topics and the methods of analysis, but also by the variety of genres. His work shows the different genres of literary criticism. Genres such as review articles, controversies, research articles, literary portraits, essays, and literary dialogues are particularly predominant in scholarly work. The review article focuses on the poet's work based on the principles of the era, evaluating the art criteria, and drawing conclusions based on scientific analysis.

Most of the articles by I. Hakkulov are devoted to the study of Uzbek poetry, which show the profound analysis, logical consistency, openness and generalization of the truth. Critic's article "Let the Word Make Life" (6.178) is a scientific-theoretical review that examines the style, skill and mastery of the 20th century Uzbek poetry. The sensitivity of the language spirit in the poems of Hamid Olimjon and
Zulfiya attracts the attention of the scientist, but the passion in Shukrullo's work is critically acclaimed.

The correct choice of words in the poems of E. Vahidov and A. Aripov, and in the literary works of all poets in our critical literature, pleased with the correct and appropriate use of words in the works of a number of young poets U.Azim, H.Davron, S.Rahmon, T.Jura, and Yuldash Eshbek. The unevenness, superficiality in the choice of words, and the wrong choice of words, as well as the fact that some poets exist in the work of the poets.

For example, the royals of Ramaz Babajan were analyzed, and the ternary analysis of why the words in the rubais were inconsistent. Moreover, poets such as Husniddin Sharipov, N. Narzullaev, Sayyor express their disapproval of the use of words, and the value of the word is irrelevant because the words are colorless and the meaning is weak. For example, words in a number of sartorial poems such as, "When you wipe the onion, I shed tears"; is decomposed. After all, is it possible to say, "He made the mountain from the dust?" $(6,186)$.

One of the peculiarities of the critic's approach is to ask the reader a question and then answer it, but he does not deliberately answer the question. Because without any explanation, it is clear that mountains cannot be made from soil. The situation that the critic has objected to is the fact that the simple words are not properly used, the words are ignored, and the words are lost.

The article clearly illustrates I. Hakkulov's point of view that he is deeply concerned about the future of Uzbek poetry, with a keen insight into the meaning of the word. He argues that "True poetry is the word that resides in the heart of the reader" $(1,187)$ and strongly criticizes the work of poets who do not penetrate the heart of the reader and do not appreciate the words. With great courage and boldness he reveals the imbalance of meaning in the poem.

This article by I.Hakkulov was written in 1983. The validity of his ideas about modern poetry is being confirmed today. Today, our people love to read the poems acknowledged by the scientist, and the name of the poets who have been criticized has not been known or known today. As it turns out, the scientific and theoretical problems presented in the review article have been solved.Especially popular in the literary criticism is the genre of essay with its wide popularity, scientific and artistic leadership, and the leadership of figurative thinking. This genre has a number of features, such as free thinking, disobeying various stereotypes, and giving freedom to imagination, which critics often refer to. The Uzbek literary criticism also reveals many examples and variations of the essay genre. In particular, the essays of Naim Karimov, Sh.Kolmirzaev, Ozod Sharafiddinov, Ibrohim Gafurov are well known to many and are well-known in our literature.

Personal essay reflects the power of the author's artistic mind, the skill and scope, the life experience, the wisdom of the writer, the ability to think [5,147]. For this reason, although there are many examples of this genre in our literature, they do not overlap. There are several examples of the essay genre in the works of literary scholar and critic I.Hakkul, many of which are related to the literary ideas of the essay. Literary ideas about the representatives of Uzbek 
literature such as "Ahmad kalla", "Abdulla Qahhor darility", "Ilm shukuhi", "Great Love of the Heart", "Artist of Life" dedicated to world classics are examples of creative work.

There is a wide range of the literary thoughts of the critic, devoted to Ahmad Donish, in which the proud and hard-working life of the great artist is illustrated by various sources. In the eyes of the reader, he was able to visualize not only the appearance of Donish, but also the complex and perilous scenes of his time. At the beginning of the article I. Hakkul A. Donish gives a brief overview of the role of literature in literature, its character and accuracy. And every thought expressed in it will be portrayed in subsequent sections of the essay with a strong passion, opening to individual readers in the context of A. Donish's life path.

One of the leading qualities of an essay is the ability to think freely and to have an independent plot, structure, and content based on heroic interior designs [2,375]. This feature can also be seen in Ahmad Kalla. The essay contains several independent plot lines that have their own heroes who, in turn, relate to A. Donish's life. In particular, the reader will be impressed with the plot lines related to the poet Vakif and S. Aini.

This essay by critics reveals not only Ahmed Donish's work in literature but also other new dimensions. In particular, A. Donish in the essay shows:

- A skilful and capable secretary;

- a fair and intelligent politician, caring for the people;

- Defender of the people, who condemns the truth

- a talented astrologer,

- Talented artist and artist,

- A caring teacher.

One of the specifics of Essay is its wide range. The reader not only gets acquainted with A. Donish in the process of reading it, but also learns about the political situation of the poet's life, his attitude towards the people of science, who studied his works. The essay concludes with an uplifting optimism and urge to create a sense of pride and pride in the reader and to be worthy of ancestors. In the essay, the feelings of Hakul were illustrated. The feeling of pride for his countryman, such as Ahmad Donish, is reflected in his essay, in his essay, in illuminating his image, his overcoming the obstacles of Donish's life, his exemplary and honorable life.

In particular, the scientist suffers from not knowing where the grave of Donish is, or the lack of any special research on the identity and needs of the new era. Ibrahim Haqqulov's essay, "The Courage of Abdullah Qahhor" is also peculiar with its peculiarities, namely, the high pope, the syncretism of scientific and artistic style, the ability to express new ideas about the critic A.Kahhar through his article.

In the process of creating Chekhov's portrait, Khakulov links the subject with the ideas of the artistic art of the old "Futuvvatnoma". It compares the virtues of the writer with the ideals of the Oriental peoples, and it is clear from the comparisons that Chekhov's innermost are many of them. The purpose of this comparison is to bring the author closer to the reader, to understand that the topics he is addressing are not strange to us.

\section{ANALYSIS AND RESULTS}

Apparently, scholars have used various methods of analysis in textual analysis, especially in the use of the historical and cultural methodology, and have been able to create new and well-grounded analysis. He went deep into the creative lab and realized that his purpose in writing the work was to understand what he wanted to say. In particular, the use of this method in the analysis of Navoi's creativity and the focus of the doctrine of the mysticism on the researcher make it closer to the great poet's mentality and worldview. The fact that the analysis of Navoi's work is analyzed in such a new way is unique in that each discussion is based on deep knowledge and comparisons. The genre composition of the critique is also diverse, with all the features of its scientific and theoretical review: 1. Scientific analysis is given. 2 . The analyzed works are based on the leading principles of the period and relate to the studied literary phenomenon (recent periods of Uzbek poetry of the 20th century) Literary evidence was analyzed on the basis of consistent practical aesthetic logic. 3. Poems analyzed in the review article are rated according to art criteria. 4. Theoretical conclusions based on the analysis are summarized.It is clear from the analysis that Hakulov's essays do not duplicate each other, but have a different style, color, and color. Still, there are points that connect them. This is the concept of life of the critics, honesty, correctness, deep thinking. This also shows the critic's uniqueness in choosing a hero. Critical essays are not intended to introduce the writer or artist to the reader. What the scientist wants to draw from the student is their exemplary life, imitating it. Ibrahim Haqqulov analyzes the inner world of the heroes and evaluates them in terms of humanity and nobility. Therefore, they do not discriminate between the West and the East based on separate criteria.

\section{CONCLUSION}

Through the analysis, Ibrahim Haqqulov's creativity, style and skills can be evaluated as follows:

1. Ibrohim Khakkulov is a classical literary critic and especially a skilled scientist in naval science.

2. Sophisticated studies of the scholar require a thorough study.

3. The methodology of literary comparisons (sharp western emblem) prevails in literary observations. In Khakkulov's analysis, there is clearly unity of science and art, and that no word in the book has been left from the attention of the critic.

4. Critical Evaluator of Contemporary Literature. A complete study of writings of a scientist is one of the major challenges in literature.

5. Criticism is diverse in terms of techniques. Proper selection of methods that fully capture the content of the text and the depth of the analysis are characteristic of the scholarly method.

6. The works of Ibragim Haqqulov are important because of their vibrancy and 
fiction, the depth of the discussion and the relevance of the selected heroes to this day.

7. No matter who wrote the critic, he could say something new. He sought to portray the heroes of the article, to portray them as much as possible, to approach the reader.

8 . The works of the critic are universal and philosophical, and the opinions expressed in them are vital considerations for readers.

9. Most importantly, in all the articles, books, or interviews of Ibrahim Khakkul, there is literary challenges. It defines the high status of literature and it is also the core of the national ideology of independence.

\section{REFERENCES}

1. Sharafiddinov O. Awesome Understanding of Creation. Tashkent. 2006.

2. B.Nazarov, A.Rasulov, Sh.Ahmedova, Q. Kahramonov. "History of Uzbek Literary Criticism", Textbook. Tashkent, "Wing of the Tafakkur". 2012.

3. Haqqulov I. Fate and obedience. Tashkent. "Sharq". 2007.

4. Hakulov I. Spirituality and Perception. T. "Spirituality", 1998.

5. Back to Navoi. Tashkent. "Fan". 2011. Book 2

6. Ш.Ахмедова.Ўзбек адабий танқидчилиги жанрлари. Тошкент.2008

7. И.Хаққул. Хаёт, адабиёт ва абадият.Тошкент.2019

8. Кўшжонов М. Қалб ва қиёфа. Тошкент. АСН. 1978. 62-бет.

9. Қаюмов Л. Аср ва наср. Тошкент. АСН. 1975. 251-252-бетлар 